\title{
EFFECT OF EXPORT PROMOTION PROGRAMS ON EXPORT PERFORMANCE: EVIDENCE FROM MANUFACTURING SMES
}

\author{
Xiaoting WANG', Aihua CHEN², Huafeng WANG ${ }^{3}$, Shengxiao $\mathrm{LI}^{4}$ \\ 1, 3,4 School of Business and Management, Shaoxing University, \\ 900 Chengnan Avenue, Shaoxing 312000, China \\ ${ }^{2}$ School of Business, Jiaxing University, No. 56 Yuexiu South Road, Jiaxing 314001, China \\ E-mails: 1wangxt@zju.edu.cn (corresponding author); ${ }^{2}$ chenaihuazwb@zju.edu.cn; \\ 3whftony@163.com; ${ }^{4}$ lsx_3100@163.com \\ Received 29 September 2015; accepted 28 December 2016
}

\begin{abstract}
The objective of this paper is to examine how a firm's participation in government export promotion programs (EPPs) may lead to a better export performance. Based on dynamic capabilities perspective, a mediated moderation model of EPPs on export performance was proposed and tested in Chinese manufacturing SMEs. The results show marketing implementation capabilities mediate the effect of information-related programs on export performance, and the financial aid-related EPPs moderate the process. The results contribute to the studies relating EPPs and export performance, as the results confirm the instrumental role of EPPs in enhancing export performance and examine the interplay between different types of EPPs. This study provides a guideline for managers as to how they can benefit from government EPPs. The findings also imply that policy makers should develop EPPs with a specific emphasis rather than a general goal of export performance.

This study develops new insights on how export ventures exploit EPPs to develop useful capabilities. Also, the study expands current thinking on exporting by recognizing that different types of EPPs affect exporting.
\end{abstract}

Keywords: small and medium-sized enterprises, export promotion programs, export performance, China, dynamic capabilities perspective, marketing capabilities.

JEL Classification: F23, F13.

\section{Introduction}

There has been a growing interest in the internationalization and the export literature concerning the effects of EPPs in helping export ventures achieve superior performance in international markets (Francis, Collins-Dodd 2004). However, previous research has shown mixed evidence about the relationships between EPPs and export performance. While some studies show a positive effect of EPPs on export outcome (Lages, Montgomery 2005; Shamsuddoha et al. 2009), others demonstrate non-significant impact or the impact is rather small (Ayob, Freixanet 2014). Thus, there is an important need to look into enabling factors as well as the processes underlying the performance impacts 
of EPPs. Moreover, previous research has paid little attention to a potential interplay between different types of EPPs in helping ventures achieve better performance.

In this study, we seek to unpack the process and examine the enabling factors to explain how a firm's participation in various government programs may lead to a better export performance. Based on dynamic capabilities perspectives (Teece et al. 1997), we argue that marketing implementation capabilities may play an instrumental role in mediating the impacts of EPPs on export performance. Also, unlike most of previous research (Leonidou et al. 2011), we argue that there would be joint effects of different types of EEPs. We propose a mediated moderation model of EPPs on export performance; thereby marketing implementation capabilities are identified as a mediating variable in the relationship between information-related EPPs and export performance, and the financial aid-related EPPs moderate the process. Among various types of EPPs, we focus on information and financial programs because: (i) they are the most available public export assistance for SMEs; (ii) lack of available information and the unavailability of export financing have been regarded as the top factors that limited SMEs' abilities to export (Mahone 1991).

This research makes several important contributions to the literature. First, by investigating the performance impact of EPPs, we theorize the joint effects of information and financial programs on the development of a firm's marketing implementation capabilities. Second, by examining the mediating role of marketing implementation capabilities, we reveal an enabling factor in the transformation of government EPPs into competitive advantages of export ventures. Third, we develop a new insight into how export ventures acquire various programs for developing useful capabilities and thereby leading to performance outcomes. To address the key issues outlined above, we provide an overview of the relevant literature, which is followed by a mediated moderation model of EPPs on export performance and theoretical development of hypotheses. Using a sample of Chinese manufacturing SMEs, the model and hypotheses are examined. Theoretical significance and managerial implications are discussed in the last section.

\section{Conceptual background}

\subsection{Government EPPs}

Government EPPs are public policy measures offered to business community with the aim to improve the international competitiveness of domestic firms (Lages, Montgomery 2005). The domain of EPPs includes giving export information and advice, marketing support, financial support and guarantees, and promotional activities abroad (Cavusgil, Yoeh 1994). The programs are used to help firms develop managers' positive perception toward international operations (Shamsuddoha et al. 2009), reduce mental or actual barriers to exporting (Leonidou 2004), and enhance the capabilities that are crucial to success in foreign markets (Tesfom, Lutz 2008).

Developing countries widely adopt EPPs to enhance exporting activity (Tesfom, Lutz 2008). Empirically, the role of EPPs has been supported in countries such as Eritrea (Tesfom, Lutz 2008), Bangladesh (Faroque, Takahashi 2015; Shamsuddoha, Ali 2006) and Malaysia (Ayob, Freixanet 2014). 


\subsection{EPPs and export performance}

Although prior studies have recognized EPPs' importance in firm's exports, empirical results are inconsistent. While some research indicates the adoption of EPPs has a direct and positive impact on export outcome (Francis, Collins-Dodd 2004; Sousa, Bradley 2009), or through the intervening effects of factors such as firms' capabilities, resources, and strategies (Shamsuddoha, Ali 2006; Shamsuddoha et al. 2009), other research demonstrates non-significant impact of EPPs (Ayob, Freixanet 2014; Cadot et al. 2015). Furthermore, some research suggests a more complex association between EPPs and export performance. Gengtiirk and Kotabe (2001) find both direct and joint effects of EPPs (with export involvement) on performance, and Lages and Montgomery (2005) suggest that there are positive direct effect and negative indirect effect of EPPs, which lead to non-significant total effects on export performance. To date, findings on this question are inconclusive. Some studies have confirmed the instrumental role of national EPPs in helping firms achieve superior export performance (Leonidou et al. 2015), but others have found no significant relationships. For example, Geldres-Weiss and Carrasco-Roa (2016) assess the impact of EPPs on firm's export sales by using longitudinal data of Chile, and find that although the ex-ante and ex-post differences in export performance between users and non-users are positive, when comparing the groups that have used the programs, the results did not indicate significant differences. In addition, the performance effects of financial and information programs also attract attention. The benefit of the financial programs is empirically supported (De Falco, Simoni 2014; Shamsuddoha et al. 2009). Yet the evidence of the information programs' impact is inconclusive: both positive and negative effects are found (Faroque, Takahashi 2015; Leonidou et al. 2011; Wilkinson, Brouthers 2000).

Existing studies have explored factors affecting the relationship between EPPs and export performance to explain the complexity. Most of them pay great attention to organization-level factors, and these studies can be categorized into three groups. The first one focuses on firm demographics and export characteristics, emphasizing their interplay with EPPs adoption (Ayob, Freixanet 2014; Gengtiirk, Kotabe 2001). The second group deals with the mediating role of export strategy in EPPs adoption process (Lages, Montgomery 2005; Shamsuddoha, Ali 2006). The third group tries to explain that EPPs are instrumental in augmenting organizational resources and capabilities, which subsequently, contribute toward export performance (Leonidou et al. 2011; Shamsuddoha et al. 2009).

The above review suggests, first, that EPPs matter for export performance but their effects remain inconclusive. Second, it may not be productive to focus only upon the main effects of EPPs on export performance. An in-depth research needs to investigate how organizations intervene the manifestation of EPPs in relation to export outcomes. Third, researchers have only identified the interaction of EPPs and export or firm characteristics, while the potential interplay between different types of EPPs is ignored. 


\section{Conceptual model and hypotheses}

The dynamic capabilities perspective (Teece et al. 1997) asserts that in situations of rapid and unpredictable change, it is the dynamic capabilities by which firm managers "integrate, build, and reconfigure internal and external competencies to address rapidly changing environments" (Teece et al. 1997: 516) rather than the current resource endowments that determine firm's superior performance. In the exporting context, export venture's capabilities of adapting to the requirements of its target export market is the primary determinant of performance (Cavusgil, Zou 1994). Particularly, marketing implementation capabilities are seen to be important in determining export venture's success in adapting to the dynamic market environments (Morgan et al. 2012, 2003). We assume that marketing implementation capabilities act as the instrument linking EPPs participation with export performance. And different types of EPPs may have an interaction on marketing implementation capabilities, as presented in Figure 1.

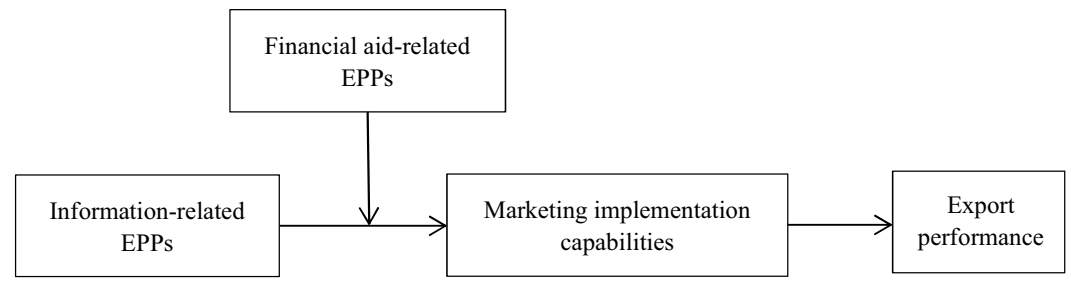

Fig. 1. The research model

\subsection{Mediating role of marketing implementation capabilities}

Marketing implementation capabilities are concerned with strategy execution as they are "the routines by which export ventures transform intended export marketing strategy into realized actions and resource deployments" (Morgan et al. 2003: 295). Without marketing implementation capabilities, resources can't be transformed into value offerings in marketplace. Thus, marketing implementation capabilities are directly related to the venture's success in adapting to its market environment (Fang, Zou 2009).

Information is crucial for firms transcending boundaries since it could reduce the high level of uncertainty of foreign markets (Leonidou, Theodosiou 2004). The informationrelated EPPs could provide firms with the necessary information to keep expanding abroad, help them understand the requirements of their target export markets and monitor changes of international business environment (Leonidou, Theodosiou 2004).

However, EPPs don't automatically result in firm sales. Information-related EPPs would be ineffective if the firm does not have the capability to utilize information provided by the EPPs and transform it into real actions. Therefore EPPs may be necessary, but not sufficient for firms to compete in international markets (Gengtiirk, Kotabe 2001; Seringhaus 1986).

We propose that adoption of information-related EPPs enhances firm's marketing implementation capabilities, which in turn, drive superior performance. Firm's internation- 
alization is an inherently uncertain undertaking: this is particularly true when firm from emerging markets steps into unfamiliar and also potentially more challenging foreign markets. Managers have little information about how to alter the resource base to address to the unfamiliar environments, which may engender inferior performance. With the assistance of the information-related EPPs, managers get a better understanding of resource complementary demands regarding target export market for now and in the near future, which contribute to the integration and reconfiguration of organizational resources for implementing marketing decisions with effectiveness and efficiency. For example, Feiyue Group, which developed from a small family firm to the world's largest producer of sewing machines, attributes its success to the Canton Fair - China's largest biannual trade event sponsored by National Ministry of Commerce. For participants, this fair not only serves as a channel to connect with international clients but also provides large amounts of export-related information. Using the information, Feiyue Group could provide overseas buyers with cost-effectiveness and high-quality products (Zhuan, 2016) Therefore, we posit that:

H1: The relationship between the information-related EPPs adaption and export performance is mediated by marketing implementation capabilities.

\subsection{Moderating role of the financial aid-related EPPs}

Dynamic capability perspective posits that, sustainable competitive advantage is achieved when firms are able to seek greater strategic integration between multiple resources (Hung et al. 2010). Among various types of resources, financial resources are the most generic type and can be relatively easy to be transformed into other types of resources. Therefore, access to financial resource could alleviate resource constraints in other aspects to some extent (Wiklund, Shepherd 2005). Moreover, acquisition of financial resource could facilitate resource-consuming behavior through providing financial slack. As an example, Wiklund and Shepherd (2005) indicate that small business' access to financial resource facilitates its implementation of entrepreneurial orientation, thus magnifies the relationship between entrepreneurial orientation and performance. Another example is demonstrated in Boso et al.'s (2012) research, which shows that access to financial resource amplifies the complementary effect of entrepreneurial and market orientations on the success of export of new products. Although these researches were not developed to target the specific case of EPPs, they provide important insights of financial resource's role played in the exporting context.

We propose that financial aid-related EPPs facilitate the information-related EPPs adoption process. First, financial aid-related EPPs provide firms with financial slack to utilize information-related programs. When participating in the information-related EPPs, managers evaluate the usefulness and appropriateness of different types of information based on conditions of the firm and characteristics of target export markets, which is a resource-consuming process. Access to more export-related financial resources means more capable staff and better information-processing infrastructure, which help firms deal with information more efficiently.

Second, firms with high adoption of financial aid-related EPPs have more financial resources (Shamsuddoha et al. 2009), which allow managers the slack to develop an 
optimal strategy that may be resource-demanding (Lin, Liu 2012). With the external support of the financial programs, managers will be in a better position to choose the organizational structure, behaviors or processes that execute the strategy more effectively. Conversely, firms with low level of adoption of the financial aid-related EPPs may be constrained in resource allocation and deployment, resulting in low efficiency in transforming intended export marketing strategy into realized actions. Thus:

H2: The financial aid-related EPPs moderate the relationship between the informationrelated EPPs and marketing implementation capabilities, such that the informationrelated EPPs have a greater impact on marketing implementation capabilities at higher levels of the financial aid-related EPPs adoption.

\section{Method}

\subsection{Research setting}

We investigate the research model by using samples of Chinese manufacturing SMEs. China represents an appropriate lens because China's export accounted for a trivial proportion of worldwide export in the initial period, China has achieved remarkable growth of exports in recent decades with governmental promotion assistance.

Chinese governments provide various public information services for foreign trade, including regional trade statistics, supply and demand information, policy announcement and interpretation, etc. The financial aid-related EPPs comprise of tax rebates, export credit, export credit guarantees, direct subsidy and special funds for exporting. Table 1 listed China's national special funds program.

Table 1. China's national special funds program

\begin{tabular}{|c|c|c|}
\hline National Special Funds & Target firms & Content \\
\hline $\begin{array}{l}\text { International market } \\
\text { development fund for } \\
\text { SMEs }\end{array}$ & $\begin{array}{l}\text { Enterprises whose volume } \\
\text { of imports and exports } \\
\text { was } 450 \text { million US } \\
\text { dollars or below last year }\end{array}$ & $\begin{array}{l}\text { Fund provided for } 11 \text { activities including } \\
\text { holding or participating in overseas } \\
\text { exhibitions, certification of administrative } \\
\text { system and products, publicity and } \\
\text { recommendation to international markets, } \\
\text { organizing trainings and seminars, overseas } \\
\text { bidding, etc. }\end{array}$ \\
\hline $\begin{array}{l}\text { Special fund for foreign } \\
\text { investment cooperation }\end{array}$ & $\begin{array}{l}\text { Firms that are } \\
\text { authenticated to undertake } \\
\text { foreign investment } \\
\text { cooperation }\end{array}$ & $\begin{array}{l}\text { Fund provided for overseas investment, } \\
\text { overseas construction contracts projects, } \\
\text { foreign labor cooperation }\end{array}$ \\
\hline $\begin{array}{l}\text { Special fund for culture } \\
\text { products development }\end{array}$ & Cultural firms & $\begin{array}{l}\text { Fund provided to foster exports of large- } \\
\text { scale cultural products and services }\end{array}$ \\
\hline $\begin{array}{l}\text { Annual discount interest } \\
\text { funds for technology } \\
\text { export }\end{array}$ & $\begin{array}{l}\text { Firms whose technology } \\
\text { export proceeds was } 500 \\
\text { thousand US dollars or } \\
\text { above }\end{array}$ & $\begin{array}{l}\text { Fund provided for assignment of patent } \\
\text { rights, rights to apply for patents, licensing } \\
\text { of rights to implement patents, assignment } \\
\text { and licensing of technical know-how, } \\
\text { technical service, etc. }\end{array}$ \\
\hline
\end{tabular}

Source: Author adaptation from YMBC (2012). 


\subsection{Sample and data}

The data for this study came from Chinese manufacturing SMEs. We selected the firms on the basis of the following criteria: (i) the volume of imports and exports was no more than 450 million US dollars in the previous year (definition of SME exporters according to Chinese national standard); (ii) manufacturing businesses with three or more years of exporting operations; and (iii) with the use of national EPPs. We targeted current rather than potential exporters because EPPs play different roles for the two types of exporters (Ahmed et al. 2002).

We applied two methods to collect data from targeted firms. The first method was to use local research assistants to conduct interview-based questionnaire surveys with top managers. The assistants visited almost 300 firms and collected 141 responses. We received 82 complete responses after excluding responses with missing data on the major variables. The other method was to deliver questionnaires with the aid of local government research agencies who were conducting a larger data collection related to exporting. As a result, another 61 complete responses were received.

Finally, we got a total of 143 firms in our sample. We did a comparison of the two waves of data and found no significant differences. On average, the participating firms have been in operation for 10.7 years, and employ 110 people. They have 8.3 years of export experience, operate in 5 foreign markets, and the exports ratio to total revenue is $54.7 \%$.

\subsection{Scale development}

We identified appropriate scales for the focal constructs after a careful review of the extant relevant literature. Scales of EPPs adoption were originated from Leonidou et al. (2011), and the marketing implementation capabilities were measured in line with four items employed in Morgan et al. $(2003,2009)$ studies. We operationalized the construct of export performance using a four-item scale derived from Morgan et al. $(2006,2012)$.

To control for export market and firm heterogeneity, we also collected data on competitive intensity using Jaworski and Kohli's (1993) scale, log difference GDP per capita 2012-2013, using total employee numbers as an indicator of firm size, and measuring export experience by years that the firm has been engaged in exporting operations. If the sample ventures have more than one export markets, we asked the respondent to focus on the largest market in terms of sales volume.

\section{Results}

\subsection{Measurement model}

We initially conduct exploratory factor analysis (EFA) and reliability analysis to identify and then exclude poorly performing items which exhibit low factor loadings. Then a confirmatory factor analysis (CFA) with the remaining items is performed to verify the hypothesized factor structure. As shown in Table 2, this measurement model fits well, with chi-sqaure $=229.940, \mathrm{df}=142, \mathrm{CFI}=0.936, \mathrm{TLI}=0.923, \mathrm{RMSEA}=0.066$. The standardized loadings of remaining items are all greater than 0.6 . Table 3 presents a correlation matrix of the main variables. 
Table 2. Construct measurement and CFA results

Research Constructs

Standardized

Loadings $^{\mathrm{a}}$

National EPPs Adoption (Five-point scale with anchors "not adopted"

to "fully adopted" in the last three years)

Information-related national EPPs $(\mathrm{CR}=0.889, \mathrm{AVE}=0.616)$

- Information about foreign market opportunities ${ }^{\mathrm{b}}$

$0.742(16.905)$

- Specific information about doing business with a particular firm

$0.866(29.609)$

- General information about doing business in a specific country

$0.794(21.296)$

- Provision of marketing information/advice

- General literature on how to export

$0.754(17.882)$

- Export publications ${ }^{\mathrm{c}}$

Financial aid-related national EPPS $(\mathrm{CR}=0.813, \mathrm{AVE}=0.521)$

- Special funds ${ }^{\mathrm{b}}$

$0.717(13.827)$

- Export credit guarantees

- Export loans

$0.777(17.024)$

- Direct subsidy on exporting ${ }^{\mathrm{c}}$

- Export rebates

$0.679(12.294)$

Marketing Capabilities (Five-point scale with anchors "strongly agree" to "strongly disagree" relative to major competitors)

Marketing implementation capabilities $(\mathrm{CR}=0.886, \mathrm{AVE}=0.662)$

- Effectively translating planned export marketing strategies into action ${ }^{\mathrm{b}}$

- Allocating appropriate resources to execute export marketing strategies

- Monitoring the performance of export marketing strategies

- Organizing to deliver planned export marketing strategies effectively

Export performance (Five-point scale with anchors "much worse" to "much better" relative to major competitors in the last three years)

Export performance $(\mathrm{CR}=0.864, \mathrm{AVE}=0.614)$

- Export venture's market share growth ${ }^{\mathrm{b}}$

- Growth in export venture sales revenue

- Acquiring new export venture customers

- Increasing sales to current export customers

$0.805(20.732)$

Export market characteristics (Five-point scale with anchors "strongly agree"

to "strongly disagree")

Competitive intensity $(\mathrm{CR}=0.661, \mathrm{AVE}=0.496)$

- Competition in this export market is cutthroat ${ }^{\mathrm{c}}$

- There are many "promotion" wars in this export market ${ }^{\mathrm{b}}$

- Price competition is a hallmark of this export market ${ }^{\mathrm{c}}$

- One hears of a new competitive move in this market almost every day

$0.770(5.765)$

Notes: ${ }^{\mathrm{a}} \mathrm{t}$-values are in parentheses; ${ }^{\mathrm{b}}$ Item fixed to set the scale; ${ }^{\mathrm{c}}$ Item excluded as a result of scale purification procedures.

Fit statistics for structural model: $\chi^{2}(142)=229.940, \mathrm{p}<.001 ; \mathrm{CFI}=0.936$; TLI $=0.923$; RMSEA $=$ 0.066 . 
Table 3. Correlations and descriptive statistics

\begin{tabular}{lccccccc}
\hline \multicolumn{1}{c}{ Constructs } & Mean & s.d. & (1) & (2) & (3) & (4) & (5) \\
\hline (1) Information-related EPPs & 4.21 & 0.773 & 1.00 & & & \\
\hline (2) Financial aid-related EPPs & 3.82 & 0.788 & $0.672^{* *}$ & 1.00 & & \\
\hline (3) Marketing implementation capabilities & 3.68 & 0.814 & $0.372^{* *}$ & $0.521^{* *}$ & 1.00 & \\
\hline (4) Export performance & 3.52 & 0.778 & $0.305^{* *}$ & $0.436^{* *}$ & $0.682^{* *}$ & 1.00 \\
\hline (5) Competitive intensity & 3.40 & 0.811 & 0.155 & $0.380^{* *}$ & $0.285^{* *}$ & $0.279^{*}$ & 1.00 \\
\hline
\end{tabular}

Notes: ${ }^{*} \mathrm{p}<0.05 ; * * \mathrm{p}<0.01$.

Because most of the variables in the survey are self-reported and collected via the same source, it's necessary to test the existence of common method bias (Podsakoff et al. 2003). We took several procedures to ensure common method variance was not a critical concern. First, when designing the survey, we asked questions about facts rather than perceptions whenever possible, thus reducing subjectivity in self-reporting. Second, we asked the respondents to respond anonymously for the purpose of alleviating social desirability. Third, we ran Harman's one-factor test to check if common method bias existed. Results showed that no single factor could be extracted from the data to explain most of the variance, suggesting that common method bias did not pose a problem in our investigation.

\subsection{Structural model}

We test research Hypotheses $\mathrm{H} 1$ and $\mathrm{H} 2$ employing the MPLUS software version 7. In estimating the interaction effects of the information and financial programs, we follow the Latent Moderated Structural Equations (LMS) approach recommended by Klein and Moosbrugger (2000). First, we multiply the two latent variables information and financial programs to generate the interaction term. Then, the two models below are investigated:

Marketing implementation capabilities $=\mathrm{b}_{0}+\mathrm{b}_{1}$ Information-related EPPs + $\mathrm{b}_{2}$ Financial aid-related EPPs $+\mathrm{b}_{3}$ Information-related EPPs $\times$

Financial aid-related EPPs $+e$.

Export performance $=\mathrm{b}_{0}{ }^{\prime}+\mathrm{b}_{1}{ }^{\prime}$ Marketing implementation capabilities +

$\mathrm{b}_{2}{ }^{\prime}$ Information-related EPPs $+\mathrm{b}_{3}{ }^{\prime}$ Financial aid-related EPPS +

$\mathrm{b}_{4}$ Information-related EPPs $\times$ Financial aid-related EPPs +

$\mathrm{b}_{5-8}$ Control variables $+e$.

We generate a new variable $b_{1} \times b_{1}{ }^{\prime}$ by multiplying the coefficient $b_{1}$ and $b_{1}{ }^{\prime}$. If $b_{1} \times b_{1}{ }^{\prime}$ is statistically significant, the mediating role of marketing implementation capabilities between the information-related EPPs and export performance (H1) would be supported; and if $b_{3}$ is statistically significant, the moderating role of financial-related EPPs on the relationships between the information-related EPPs and marketing implementation capabilities (H2) would be supported. 
Table 4 reports the parameter estimates. We don't report the regular model fit indices except information criteria because MPLUS does not provide the indices when carrying out numerical integration required for LMS approach. Both the coefficient $b_{1}$ and $b_{1}{ }^{\prime}$ is positive and significant, so is their product $b_{1} \times b_{1}{ }^{\prime}(\beta=0.186, p<0.01)$, supporting $\mathrm{H} 1$. The coefficient $\mathrm{b}_{3}$ is also significantly positive $(\beta=0.134, \mathrm{p}<0.1)$, supporting $\mathrm{H} 2$ (Figure 2). Therefore, both the hypotheses are statistically supported.

Table 4. Path coefficients and t-values for the structural model

\begin{tabular}{lccc}
\hline \multicolumn{1}{c}{ Paths } & Coefficient & t-Value & Status \\
\hline $\begin{array}{l}\text { Information-related programs } \rightarrow \text { marketing implementation } \\
\text { capabilities }\left(\mathrm{b}_{1}\right)\end{array}$ & $0.355^{* *}$ & 4.246 & \\
\hline $\begin{array}{l}\text { Financial aid-related programs } \rightarrow \text { marketing implementation } \\
\text { capabilities }\left(\mathrm{b}_{2}\right)\end{array}$ & $0.134^{*}$ & 1.791 \\
\hline $\begin{array}{l}\text { Information-related programs } \times \text { financial aid-related } \\
\text { programs } \rightarrow \text { marketing implementation capabilities }\left(\mathrm{b}_{3}\right)\end{array}$ & $0.134^{*}$ & 1.791 \\
\hline $\begin{array}{l}\text { Marketing implementation capabilities } \rightarrow \text { export } \\
\text { performance }\left(\mathrm{b}_{1}{ }^{\prime}\right)\end{array}$ & $0.523^{* *}$ & 5.357 & \\
\hline Information-related programs $\rightarrow$ export performance $\left(\mathrm{b}_{2}{ }^{\prime}\right)$ & -0.043 & -0.395 & \\
\hline Financial aid-related programs $\rightarrow$ export performance $\left(\mathrm{b}_{3}{ }^{\prime}\right)$ & 0.136 & 1.155 & \\
\hline $\begin{array}{l}\text { Information-related programs } \times \text { financial aid-related } \\
\text { programs } \rightarrow \text { export performance }\left(\mathrm{b}_{4}\right)\end{array}$ & -0.090 & -1.291 & \\
\hline Competitive intensity $\rightarrow$ export performance $\left(\mathrm{b}_{5}\right)$ & 0.064 & 0.900 & \\
\hline $\begin{array}{l}\text { Log difference GDP per capita } 2012-2013 \rightarrow \text { export } \\
\text { performance }\left(\mathrm{b}_{6}\right)\end{array}$ & -0.049 & -0.037 & \\
\hline Firm size $\rightarrow$ export performance $\left(\mathrm{b}_{7}\right)$ & 0.000 & 0.011 & \\
\hline Export experience $\rightarrow$ export performance $\left(\mathrm{b}_{8}\right)$ & 0.004 & 0.517 & \\
\hline H1: $\mathrm{b}_{1} \times \mathrm{b}_{1}{ }^{\prime}$ & $0.186^{* *}$ & 3.405 & Supported \\
\hline H2: $\mathrm{b}_{3}$ & $0.134^{*}$ & 1.791 & Supported \\
\hline
\end{tabular}

Notes: ${ }^{*} \mathrm{p}<0.1 ; * * \mathrm{p}<0.01$

Information criteria for structural model: $\mathrm{AIC}=5533.963, \mathrm{BIC}=5718.835$.

We further estimate the size of indirect effect of marketing implementation capabilities and moderating effect of financial aid-related EPPs. The indirect effect through marketing implementation capabilities on export performance is $0.326\left(\left(b_{1}+b_{2}+b_{3}\right) \times b_{1}{ }^{\prime}=\right.$ $(0.355+0.134+0.134) \times 0.523=0.326)$, while the direct effect of EPPs (including the interaction) on export performance is $0.003\left(b_{2}{ }^{\prime}+b_{3}{ }^{\prime}+b_{4}=(-0.043)+0.136+\right.$ $(-0.09)=0.003)$, indicating that indirect effect through marketing implementation capabilities accounts for $99.1 \%$ of total effects $(0.326 /(0.326+0.003) \times 100 \%=99.1 \%)$. This implies marketing implementation capabilities play a key role in transforming EPPs into realized export performance.

The results also demonstrate that the financial aid-related EPPs moderate the information-related EPPs adoption process both directly and indirectly. The coefficient $b_{4}$ is 


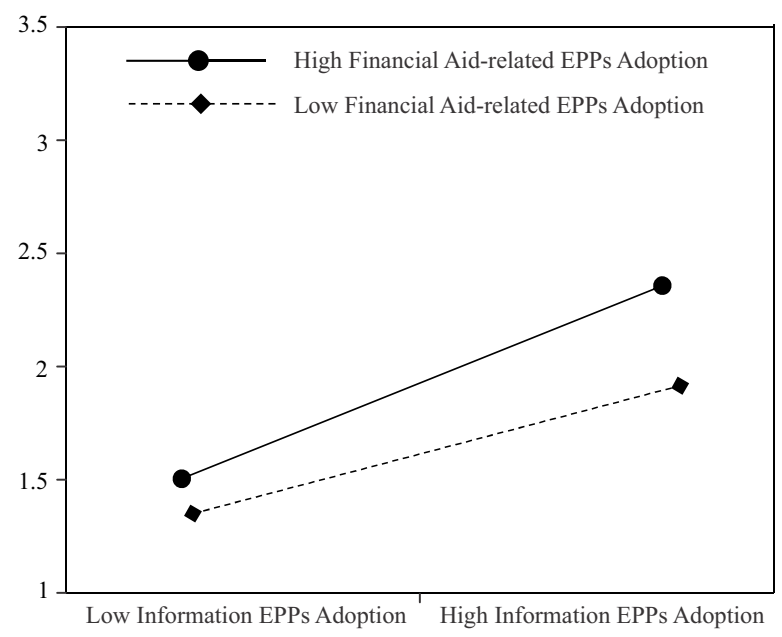

Fig. 2. Interaction between information-related EPPs and financial aid-related EPPs to predict marketing implementation capabilities

negative and non-significant $(\beta=-0.090, \mathrm{p}>0.1)$, indicating the moderating effect of the financial aid-related EPPs on the relationships between the information-related EPPs and export performance, i.e., the direct moderation. And $b_{4} \times b_{1}{ }^{\prime}$ is positive $\left(b_{4} \times b_{1}{ }^{\prime}=\right.$ $0.134 \times 0.523=0.070$ ), indicating the moderating effect of the financial aid-related EPPs on the relationships between the information-related EPPs and marketing implementation capabilities, i.e., the mediated moderation. This implies that the marketing implementation capabilities are an important route through which the two programs jointly influence export performance. Therefore, our study stresses the instrumental role of marketing implementation capabilities in adopting EPPs.

\section{Discussions and conclusions}

Research has examined national EPPs over many years, but empirical evidence on the performance effect of EPPs is inconclusive. In recognizing the instrumental role of EPPs in helping export ventures achieve superior performance, our theoretical model describes how the performance implications of information EPPs can be achieved through the mediating mechanism of marketing implementation capabilities and the moderating mechanism of financial EPPs. We tested our theoretical arguments in the context of China's manufacturing SMEs. The findings provide supporting evidence for the mediated moderation model of EPPs on export performance.

This investigation generates several contributions to the literature. First, we provide empirical evidence to substantiate the rationale for use of EPPs, contributing to the export literature. The importance of EPPs in SMEs' internationalization is highlighted, as well as the instrumental role of marketing implementation capabilities. Second, our study extends the dynamic capabilities perspective in exporting context by examining the mediating role of marketing implementation capabilities. The findings are consistent 
with the dynamic capabilities perspective which emphasizes the role of firm's internal capabilities in explaining inter-firm performance variations. Thus, our research reinforces the importance of firm's dynamic capabilities in exporting context. Third, the present study expands current thinking on exporting by recognizing that different types of EPPs affect exporting in ways that have not yet been explored. This may help us acquire a deeper knowledge of the complexity of EPPs adoption process.

This paper presents some managerial implications for both export ventures and public policy makers. For export ventures, first, understanding EPPs' instrumental role in enhancing export performance may be helpful to the professionals and other stakeholders. Second, export ventures should place high value on their marketing capabilities. Managers need to choose organizational structure, behavior or process that could enhance marketing capabilities. For public policy makers, first, the role that marketing capabilities play in enhancing export performance implies that EPPs should be targeted based on export venture's capabilities. Second, since the adoption of multiple types of EPPs contributes to a better performance, the governments should offer firms packages of EPPs and develop EPPs in a systematical way.

This research has also economic implications for countries which aim to enhance exporting activity by using governmental means. The important role of financial programs in enhancing other EPPs' adoption is confirmed, implying that it's necessary for governments to provide financial aid to exporters. Given that trade policy is regulated by international institutions such as WTO, the governments could assist exporters financially in some other way.

Several future research directions can be explored from this paper. First, as we only focus on the joint effects of two EPPs in this research, it may be meaningful to have a closer look at the other EPPs. Second, future research could identify stages of internationalization of export firms such as reactive exporter, active exporter and committed exporter since firms with different levels of internationalization need different export assistance. Finally, the sample of the study is confined to manufacturing SMEs located in China. Future research can expand this study to other regions and beyond.

\section{Funding}

This work was supported by the National Natural Science Foundation of China under Grant [number 71572174 and 71272165$]$.

\section{References}

Ahmed, Z. U.; Mohamed, O.; Johnson, J. P.; Meng, L. Y. 2002. Export promotion programs of Malaysian firms: an international marketing perspective, Journal of Business Research 55(10): 831-843. https://doi.org/10.1016/S0148-2963(00)00223-X

Ayob, A. H.; Freixanet, J. 2014. Insights into public export promotion programs in an emerging economy: the case of Malaysian SMEs, Evaluation and Program Planning 46(4): 38-46.

https://doi.org/10.1016/j.evalprogplan.2014.05.005 
Boso, N.; Cadogan, J. W.; Story, V. M. 2012. Complementary effect of entrepreneurial and market orientations on export new product success under differing levels of competitive intensity and financial capital, International Business Review 21(4): 667-681.

https://doi.org/10.1016/j.ibusrev.2011.07.009

Cadot, O.; Fernandes, A. M.; Gourdon, J.; Mattoo, A. 2015. Are the benefits of export support durable? Evidence from Tunisia, Journal of International Economics 97(2): 310-324.

https://doi.org/10.1016/j.jinteco.2015.07.005

Cavusgil, S. T.; Yoeh, P. L. 1994. Public sector promotion of U.S. export activity: a review and directions for the future, Journal of Public Policy \& Marketing 13(1): 76-84.

Cavusgil, S. T.; Zou, S. 1994. Marketing strategy-performance relationship: an investigation of the empirical link in export market ventures, Journal of Marketing 58(1): 1-21.

https://doi.org/10.2307/1252247

De Falco, S. E.; Simoni, M. 2014. The effect of public export incentives on Italian textile and fashion SMEs, International Studies of Management \& Organization 44(1): 70-83.

https://doi.org/10.2753/IMO0020-8825440105

Fang, E.; Zou, S. 2009. Antecedents and consequences of marketing dynamic capabilities in international joint ventures, Journal of International Business Studies 40(5): 742-761.

https://doi.org/10.1057/jibs.2008.96

Faroque, A. R.; Takahashi, Y. 2015. Export marketing assistance and early internationalizing firm performance: does export commitment matter?, Asia Pacific Journal of Marketing and Logistics 27(3): 421-443. https://doi.org/10.1108/APJML-03-2014-0045

Francis, J.; Collins-Dodd, C. 2004. Impact of export promotion programs on firm competencies, strategies and performance: the case of Canadian high-technology SMEs, International Marketing Review 21(4): 474-495. https://doi.org/10.1108/02651330410547153

Geldres-Weiss, V. V.; Carrasco-Roa, J. A. 2016. Impact evaluation of national export promotion programs on export firms using contrast groups, International Journal of Export Marketing 1(1): 77-95.

Gengtiirk, E.; Kotabe, M. 2001. The effect of export assistance program usage on export performance: a contingency explanation, Joumal of International Marketing 9(2): 51-72.

https://doi.org/10.1509/jimk.9.2.51.19886

Hung, R. Y. Y.; Yang, B.; Lien, B. Y.; McLean, G. N.; Kuo, Y. 2010. Dynamic capability: impact of process alignment and organizational learning culture on performance, Journal of World Business 45(3): 285-294. https://doi.org/10.1016/j.jwb.2009.09.003

Jaworski, B. J.; Kohli, A. K. 1993. Market orientation: antecedents and consequences, Journal of Marketing 57(3): 53-70. https://doi.org/10.2307/1251854

Klein, A.; Moosbrugger, H. 2000. Maximum likelihood estimation of latent interaction effects with the LMS method, Psychometrika 65(4): 457-474. https://doi.org/10.1007/BF02296338

Lages, L. F.; Montgomery, D. B. 2005. The relationship between export assistance and performance improvement in Portuguese export ventures: an empirical test of the mediating role of pricing strategy adaptation, European Journal of Marketing 39(7/8): 755-784.

https://doi.org/10.1108/03090560510601752

Leonidou, L. C. 2004. An analysis of the barriers hindering small business export development, Journal of Small Business Management 42(3): 279-302.

https://doi.org/10.1111/j.1540-627X.2004.00112.X

Leonidou, L. C.; Palihawadana, D.; Theodosiou, M. 2011. National export-promotion programs as drivers of organizational resources and capabilities: effects on strategy, competitive advantage, and performance, Journal of International Marketing 19(2): 1-29.

https://doi.org/10.1509/jimk.19.2.1 
Leonidou, L. C.; Samiee, S.; Geldres-Weiss, V. V. 2015. Using national export promotion programs to assist smaller firms' international entrepreneurial initiatives, in P. N. Ghauri,V. H. M. Kirpalani (Eds.). Handbook of research on international entrepreneurship strategy: improving SME performance globally. Cheltenham: Edward Elgar Publishing Ltd.

https://doi.org/10.4337/9781783471584.00023

Leonidou, L. C.; Theodosiou, M. 2004. The export marketing information system: an integration of the extant knowledge, Journal of World Business 39(1): 12-36.

https://doi.org/10.1016/j.jwb.2003.08.005

Lin, W. T.; Liu, Y. 2012. Successor characteristics, organisational slack, and change in the degree of firm internationalisation, International Business Review 21(1): 89-101.

https://doi.org/10.1016/j.ibusrev.2011.01.001

Mahone, Jr., C. E. 1991. Factors that restrict exports of small and medium-sized firms: the role of export financing, Journal of Small Business Strategy 2(2): 24-34.

Morgan, N. A.; Katsikeas, C. S.; Vorhies, D. W. 2012. Export marketing strategy implementation, export marketing capabilities, and export venture performance, Journal of the Academy of Marketing Science 40(2): 271-289. https://doi.org/10.1007/s11747-011-0275-0

Morgan, N. A.; Vorhies, D. W.; Mason, C. H. 2009. Market orientation, marketing capabilities, and firm performance, Strategic Management Journal 30(8): 909-920.

https://doi.org/10.1002/smj.764

Morgan, N. A.; Vorhies, D. W.; Schlegelmilch, B. B. 2006. Resource-performance relationships in industrial export ventures: the role of resource inimitability and substitutability, Industrial Marketing Management 35(5): 621-633. https://doi.org/10.1016/j.indmarman.2005.05.018

Morgan, N. A.; Zou, S.; Vorhies, D. W.; Katsikeas, C. S. 2003. Experiential and informational knowledge, architectural marketing capabilities, and the adaptive performance of export ventures: a cross-national study, Decision Sciences 34(2): 287-321.

https://doi.org/10.1111/1540-5915.02375

Podsakoff, P. M.; Mackenzie, S. B.; Lee, J. Y.; Podsakoff, N. P. 2003. Common method biases in behavioral research: a critical review of the literature and recommended remedies, Journal of Applied Psychology 88(5): 879-903.

Seringhaus, F. H. R. 1986. The impact of government export marketing assistance, International Marketing Review 3(2): 55-66. https://doi.org/10.1108/eb008306

Shamsuddoha, A. K.; Ali, M. Y. 2006. Mediated effects of export promotion programs on firm export performance, Asia Pacific Journal of Marketing and Logistics 18(2): 93-110.

https://doi.org/10.1108/13555850610658255

Shamsuddoha, A. K.; Ali, M. Y.; Ndubisi, N. O. 2009. Impact of government export assistance on internationalization of SMEs from developing nations, Journal of Enterprise Information Management 22(4): 408-422. https://doi.org/10.1108/17410390910975022

Sousa, C.; Bradley, F. 2009. Effects of export assistance and distributor support on the performance of SMEs: the case of Portuguese export ventures, International Small Business Journal 27(6): 681-701. https://doi.org/10.1177/0266242609344253

Teece, D. J.; Pisano, G.; Shuen, A. 1997. Dynamic capabilities and strategic management, Strategic Management Journal 18(7): 509-535.

https://doi.org/10.1002/(SICI)1097-0266(199708)18:7<509::AID-SMJ882>3.0.CO;2-Z

Tesfom, G.; Lutz, C. 2008. Evaluating the effectiveness of export support services in developing countries: a customer (user) perspective, International Journal of Emerging Markets 3(4): 364-377. https://doi.org/10.1108/17468800810906075 
Wiklund, J.; Shepherd, D. 2005. Entrepreneurial orientation and small business performance: a configurational approach, Journal of Business Venturing 20(1): 71-91.

https://doi.org/10.1016/j.jbusvent.2004.01.001

Wilkinson, T. J.; Brouthers, L. E. 2000. An evaluation of state sponsored promotion programs, Journal of Business Research 47(3): 229-236. https://doi.org/10.1016/S0148-2963(99)00097-1

YMBC. 2012. Data Compilation of Chinese National and Provincial Business Promotion Programs [online], [cited 15 January 2015]. Yantai Municipal Bureau of Commerce. Available from Internet: http://www.ytboc.gov.cn/article_show.aspx?id=2598

Zhuan, T. 2016. SMEs benefit from increased emphasis [online], [cited 10 December 2016]. China Daily Group. Available from Internet: http://www.chinadaily.com.cn/cndy/2016-10/10/ content_27006629.htm

Xiaoting WANG is currently an Assistant Professor PhD in the School of Business and Management, Shaoxing University. Her research interests are focused on the phenomenon of family business succession, international management and entrepreneurship.

Aihua CHEN is currently an Associate Professor PhD in the School of Business, Jiaxing University. Her research interests are focused on the management in science and education, industry-universityinstitute collaborative innovation.

Huafeng WANG is currently an Associate Professor PhD in the School of Business and Management, Shaoxing University. His research focuses on entrepreneurship and work-family conflict.

Shengxiao LI is currently a Professor of marketing and strategy in the School of Business and Management, Shaoxing University. His research focuses on the sustainable development of private-owned business. He is also a Business Consultant and Marketing Expert, independent director of several Chinese listed companies. 